\title{
Blood cadmium levels increase prostate specific antigen and insulin-like growth factor-1 among cadmium exposed workers
}

\author{
Nendyah Roestijawati*, Lintje Setyawati Maurits*, and Sugiyanto*
}

\begin{abstract}
* Department of Public Health and Community Medicine

Faculty of Medicine Jenderal Soedirman University Purwokerto

Correspondence:

Dr.dr.Nendyah Roestijawati, MKK Department of Public Health and Community Medicine

BACKGROUND

Cadmium (Cd) is a heavy metal that is classified as a human carcinogen (group IA), one of the cancers that it can cause being prostate cancer. The development of prostate cancer on a molecular basis involves oncogenes such as insuline-like growth factor-1 (IGF-1). Prostate cancer can be detected in the laboratory through the examination of prostate specific antigen (PSA). The present study aimed to determine the relationship of Cd levels with levels of PSA and IGF-1 in exposed and unexposed workers.
\end{abstract}

Faculty of Medicine

Jenderal Soedirman University Purwokerto

Jl. Dr. Gumbreg no. 1 Mersi

Purwokerto

Phone: +62281 622022

Fax: +62281 624990

Email: nendyahr@yahoo.com

Univ Med 2017;36:42-8

DOI: 10.18051/UnivMed.2017.v36.42-48 pISSN: 1907-3062 / eISSN: 2407-2230

Received February 2, 2017

Accepted for publication April 20, 2017

This open access article is distributed under a Creative Commons Attribution-Non Commercial-Share Alike 4.0 International License

\section{METHODS \\ The study design was cross sectional. The subjects of the studycame from two groups of workers, ie. the group of $\mathrm{Cd}$ exposed workers who were welding shop workers and the group of unexposed workers who were office workers. The minimum samplesize was 85 people. The independent variable was blood $\mathrm{Cd}$ level. The dependent variables were PSA and IGF- 1 levels. Blood Cd levels were measured by atomic absorption spectrometry (AAS), while PSA and IGF-1 were measured using ELISA. Data analysis was performed using the Mann-Whitney test and the Spearman correlation test.}

\section{RESULTS}

Mean blood Cd level in the exposed workers was $6.5 \mu \mathrm{g} / \mathrm{L}$ and in the unexposed workers $2.15 \mu \mathrm{g} / \mathrm{L}$. There was a relationship between blood $\mathrm{Cd}$ and PSA levels $(\mathrm{p}<0.05)$ and between blood Cd levels and IGF-1 ( $\mathrm{p}$ $<0.05)$.

\section{CONCLUSIONS}

There was a relationship of blood Cd with PSA and IGF-1 levels.among workers. PSA and IGF-1 could be a biochemical markers of disease control in cadmium exposed workers.

Keywords: Cadmium, prostate specific antigen, insuline-like growth factor-1, workers 


\section{INTRODUCTION}

Cadmium (Cd) is a heavy metal that has carcinogenic effectson humans (group IA) according to the International Agency of Research on Cancer (IARC). Cadmiumis carcinogenic in humans, as has been determined based on studies in humans and experimental animals. Several studiesofCd exposed workers claim significant increases in lung cancer, although there is still controversy about disturbing exposures to other metals, such as arsenic or nickel. ${ }^{(1)}$ In addition to lung cancer, $\mathrm{Cd}$ is also suspected to cause prostate cancer in humans, because $\mathrm{Cd}$ accumulates in the prostate and testes, as well as in the kidneys and liver. The study showed increased $\mathrm{Cd}$ in the blood and prostate of mice injected with $\mathrm{Cd}$. The amount of $\mathrm{Cd}$ accumulated in the prostate is approximately $50 \%$ of the total $\mathrm{Cd}$ in the body and is linearly associated with the amount of $\mathrm{Cd}$ accumulated in the liver and testis.(2) Research by Guzel et al. ${ }^{(3)}$ proved the effect of $\mathrm{Cd}$ exposure on prostate cancer, with their results showing elevated Cd levels in patients with prostate cancer.

The development of prostate cancer on a molecular basis involves many gene expressions, suchas 1q24-1q25 (HPC1),1q42-q43(PCAP), Xq27-q28 (HPCX), 20q13 (HPC20), and mutations in tumor suppressor genes such as $\mathrm{p} 53$, PTEN, CDKN1B, MX11, NKX3.1, glutathione S-transferase gene (GSTP-1) and several oncogenes such as insulin-like growth factor-1 (IGF-1). ${ }^{(4)}$ IGF-1 can cause cancer through inhibition of apoptosis and stimulation of cell proliferation. Epidemiological studies reported a positive correlation of IGF-1 with prostate cancer. $^{(5)}$

The laboratory indicator for prostate cancer is prostate specific antigen (PSA). Cd is currently one of the most extensive occupational and environmental pollutants. Some studies suggest a relationship between $\mathrm{Cd}$ and PSA. The results of a study by de Coster et al. ${ }^{(6)}$ showed a significant correlation between urinary Cd levels of $\geq \mathrm{p} 90$ $(1.24 \mu \mathrm{g} / \mathrm{L})$ and PSA levels in the population group aged 50-65 years living in nine areas with different levels of air pollution.On the contrary, the results of a study by Pizent et al. ${ }^{(7)}$ found no significant association between blood Cd and PSA in men with a history of work unexposed to $\mathrm{Cd}$. This indicates that a relationship will be found between $\mathrm{Cd}$ and PSA at high Cd levels but not at low Cd levels.

Natural conditions of $\mathrm{Cd}$ release into the environment are due to the weathering of sediments from the effects of weather, erosion and volcanic activity. On the other hand, under anthropogenic conditions $\mathrm{Cd}$ is released into the environment due to human activity. Relations between $\mathrm{Cd}$ and IGF-1 have been investigated by Chen et al. ${ }^{(8)}$ The results showed a proportional relationship between $\mathrm{Cd}$ and IGF-1 levels, with higher Cd levels at high IGF-1 levels.

Workers in a large variety of occupations, especially those who are involved in the manufacture of alloys and batteries, and nonferrous metal smelting and refining, are exposed to high levels of cadmium through inhalation of dust and fumes, and incidental ingestion of dust from contaminated hands, cigarettes or foods. ${ }^{(9)}$ The high levels of blood Cd are influenced by workplace environmental factors, foods/beverages and tobacco. The $\mathrm{Cd}$ exposed workers comprise such groups as police officers, smelter workers, and workers in metal casting and welding.In nature, $\mathrm{Cd}$, such as electroplating, mining, smelting, use of pesticides, fertilizers, etc. ${ }^{(10)}$

Welding shop workers are at risk of exposure to $\mathrm{Cd}$. $\mathrm{Cd}$ sources of exposure among welding shop workers are from $\mathrm{Cd}$ fumes generated in the welding process. Cd levels in the air depend on the workplace environment for welding filler metals, the welding techniques used and the condition of the workplace. High levels of environmental $\mathrm{Cd}$ lead to high levels of $\mathrm{Cd}$ in the blood that can cause prostate cancer. Several epidemiologic studies investigating the association between $\mathrm{Cd}$ exposure and susceptibility to prostate cancer have yielded inconsistent findings. High levels of $\mathrm{Cd}$ in exposed workers was proven by the research of 
Moitra et al., ${ }^{(11)}$ which showed a significant difference in blood and urine levels of $\mathrm{Cd}$ in jewelry factory workers $(5.8 \mu \mathrm{g} / \mathrm{dL})$ as compared with those in unexposed workers, such as jewelry sales employees $(0.41 \mu \mathrm{g} / \mathrm{dL})$. The Indonesian National Standard (SNI) for Cd exposure in the workplace is $10 \mu \mathrm{g} / \mathrm{m}^{3}$ for metallic Cd and $2 \mu \mathrm{g} /$ $\mathrm{m}^{3}$ for $\mathrm{Cd}$ in the form of compounds.In men, $\mathrm{Cd}$ was associated with cancers of the lung and pancreas and with non-Hodgkin lymphoma, but not with prostate cancer. ${ }^{(12)}$

The present study aimed to determine the relationship of Cd levels with levels of PSA and IGF-1 in Cd exposed and unexposedworkers.

\section{METHODS}

\section{Research design}

This study was an observational analytic study of cross sectional design. The research was carried out in 8 months (January to August 2015) and was located in Purwokerto and Banyumas City, Banyumas District.

\section{Research subject}

The subjects of the research came from two groups of workers, one group consisting of $\mathrm{Cd}$ exposed workers and the other group consisting of unexposed workers. The $\mathrm{Cd}$ exposure group were welding workers and the group of workers unexposed to $\mathrm{Cd}$ were office workers. Thesample size was determined based on a 0.05 significance level and power of $80 \%$, with correlation of 0.3 , giving a minimum sample size of 85 people. Samples were selected by consecutive sampling in accordance with the inclusion criteria, which weremales over 30 years of age and having worked in the workplace for a minimum of 6 months. The exclusion criteria wasacquiring an acute illness (elevated body temperature) during the last 4 months.

\section{Laboratory analysis}

Blood samples were collected from the median cubital vein.Prior to blood sampling, the subjects were asked to fast for 10 hoursand not to have sexual intercourse during $2 \times 24$ hours. Blood sampling was performed at 7:00 a.m. to 9:00. Approximately $10 \mathrm{~mL}$ of blood was drawn into small purple-top vacutainer tubes. Following clotting, the blood tube was centrifuged at 2500 $3000 \mathrm{x} g$ for $5 \mathrm{~min}$. The plasma supernatant was placed in a sterile acid-washed, metal ion-free microfuge tube, and stored frozen at $-20^{\circ} \mathrm{C}$ until needed for the assays. ${ }^{(13)}$

Cadmium levels were determined using standard laboratory protocols. In brief, specimens were acid digested under high pressure in a microwave oven and then assayed for cadmium in a Perkin Elmer 3110 (Waltham, MA, USA). We used a calibration curve prepared from a serially diluted cadmium standard (Merck, Germany). ${ }^{(13)}$

PSA and IGF-1 levels were determined using human Elisa kit (Sunred Biotechnology Company, Ltd, Shanghai), based on the principle of the double-antibody sandwich technique, and assayed on an Elisa Reader 270 (Biomeureux, France).

Laboratory analysis took place at the laboratory of the Institute for Research, Faculty of Medicine, Jenderal Soedirman University, Purwokerto.

\section{Data analysis}

Data analysis to determine differences between groups was by means of the MannWhitney test, because the data were not normally distributed. Data analysis to determine whether there was a correlation, was done using the Spearman correlation test.

\section{Ethical clearance}

This study was approved by the Commission on Health Research Ethics, Faculty of Medicine, Jenderal Soedirman University (Unsoed) with Ref no: 062/KEPK/III/2014.

\section{RESULTS}

The study was conducted on 85 subjects, consisting of $40 \mathrm{Cd}$ exposed workers and 45 unexposed workers. The average age of the $\mathrm{Cd}$ 
Table 1.Subject characteristics and difference of blood Cd, PSA and IGF-1 between groups

\begin{tabular}{|c|c|c|c|}
\hline Charac teristics & $\begin{array}{c}\text { Exp osed workers } \\
(n=40)\end{array}$ & $\begin{array}{c}\text { U nexp osed w orkers } \\
(\mathrm{IF}=45)\end{array}$ & $\mathbf{p}$ \\
\hline Age (yr) & $40.43 \pm 6.68$ & $38.24 \pm 7.29$ & 0.062 \\
\hline Length of work (yr) & $1363 \pm 7.95$ & $11.20 \pm 6.47$ & 0.199 \\
\hline $\begin{array}{l}\mathrm{Blood} \mathrm{Cd}(\mu \mathrm{g} / \mathrm{L}) \\
\text { Blood PSA }(\mathrm{ng} / \mathrm{dL})\end{array}$ & $6.50 \pm 1.20$ & $2.34 \pm 0.76$ & $0.000 *$ \\
\hline $\begin{array}{l}\text { Median } \\
\text { Blood IGF-1 (ng/dL) }\end{array}$ & 3.38 & 1.96 & $0.000 *$ \\
\hline Median & 5.67 & 5.05 & 0.289 \\
\hline
\end{tabular}

*Significant 0.05 , tested by Mann-Whitney test

exposed workers was higher than that of the unexposed workers. There was no significant difference in age between exposed and unexposedworkers $(p>0.05)$. The averageof duration of work of theCd exposed workers was longer than that of the unexposed workers. There was no significant difference in duration of work between the exposed and unexposedworkers $(p>0.05)$. There was no difference in characteristics between exposed and unexposed workers, as presented in Table 1.

Statistical analysis of blood Cd, PSA and IGF-1 ofthe groups showed differencesin levels of blood $\mathrm{Cd}$ and PSA between $\mathrm{Cd}$ exposed workers and unexposed workers $(\mathrm{p}<0.05)$ but no difference in level of IGF-1 between Cd exposed and unexposed workers ( $p>0.05)$, as presented in Table 1.

The relationship between blood $\mathrm{Cd}$ and PSA was statistically significant $(r=0.445 ; p<0.05)$, being weakly positive. Similarly, the relatioship between blood Cd and IGF-1 was statistically significant $(r=0.218 ; \mathrm{p}<0.05)$, being also weakly positive, as presented in Table 2. Further analysis found a statistically significant relationship between IGF-1 and PSA ( $r=0.502 ; p<0.05)$, the relationship being moderately positive, as presented in Table 2.

\section{DISCUSSION}

The present study showed statistically significant differences in the levels of $\mathrm{Cd}$ between exposed and unexposed workers. Cd levels in exposed workerswere higher than those in unexposedworkers. The results of this study was similar with those of Golbabaei et al. ${ }^{(14)}$ in Iran, who found differences in levels of urinary $\mathrm{Cd}$ in welders and controls.

The results of our study on exposed workers showed that blood Cd concentration was $6.5 \mathrm{mg} /$ L. These resultsare different with those of the study by Idham ${ }^{(15)}$ on welders in an automotive plant in Jakarta, with the blood Cd levels ranging from $1.28 \mu \mathrm{g} / \mathrm{L}$ up to $43.33 \mu \mathrm{g} / \mathrm{L}$, and mean of $14.29 \mu \mathrm{g} / \mathrm{L}$. The differences in these results are due to the different characteristics of the workshops. The weldingprocess in Idham's research was conducted in a closed room with a ventilation system, whereas the welding process in the present study was conducted in an open location so that the metal fumes immediatelyevaporate into the surrounding air. According Golbabaei et al. ${ }^{(14)}$ welders working in an enclosed space with poor ventilation are at a 150 times higher risk than are welders in open space.

Table 2. Correlation between blood Cd, PSA and IGF-1 ( $\mathrm{n}=85)$

\begin{tabular}{lcc}
\hline \multicolumn{1}{c}{ Variable } & P SA (ng/dL) & I GF-l (ng/dL) \\
\hline BloodC d $(\mu \mathrm{g} / \mathrm{L})$ & $\mathrm{r}=0.045(0.000 *)$ & $\mathrm{r}=0.218\left(0.045^{*}\right)$ \\
BloodIGF-1 (ng/dL) & $\mathrm{r}=0.502\left(0.000^{*}\right)$ & \\
\hline
\end{tabular}

*Significant $\mathrm{p}<0.05$ (2-tailed), tested by Spearman test 
The mean blood $\mathrm{Cd}$ of unexposed workers was $2.34 \mu \mathrm{g} / \mathrm{L}$. Sources of $\mathrm{Cd}$ exposure in this group are the environment, cigarettes, foods and beverages, which contain $\mathrm{Cd}$. A total of $53 \%$ of the subjects were smokers. According to the National Research Council (US) Subcommittee on Zinc Cadmium Sulfide, the average cadmium intake through food varies between countries and individuals. Intake of nonindustrial $\mathrm{Cd}$ in rural areas is estimated to be 10-60 $\mu \mathrm{g} / \mathrm{day}$, and in a polluted area in Japan it was reported to be higher $(500 \mu \mathrm{g} /$ day $) . C d$ intake from cigarettesis estimated at 0.1-0.2 ìg per cigarette, so it can be shown that in individuals who smoke 20-40 cigarettes/day, the intake of $\mathrm{Cd}$ is $2-8 \mathrm{ig} / \mathrm{day}$. The results of the study by $\mathrm{He}$ et al. ${ }^{(16)}$ in China found that mean exposure to $\mathrm{Cd}$ was $16.7 \mu \mathrm{g} /$ day or $33.8 \%$ of the daily tolerable intake. Foods and cigarettes are a major source. $\mathrm{Cd}$ exposure from food was $12.8 \mu \mathrm{g} /$ day, while that from cigarettes was $3.9 \mathrm{mg} /$ day.

Most of the unexposed workers reside and work in urban areas. The results of research by Mohmandet al. ${ }^{(17)}$ was that one of the heavy metals contained in the air is $\mathrm{Cd}$. Cd levels in urban areas are higher than in rural areas. According to the National Research Council (US) Subcommittee on Zinc Cadmium Sulfide, in America, people who breathe $20 \mathrm{~m}^{3}$ of air per day and use $10 \%$ of their time outside their homesare estimated to absorb 0.1-0.8 $\mu \mathrm{gCd} /$ day in urban areas and less than $0.02 \mu \mathrm{g} /$ day in rural areas.

The results of ourstudy showed differences in PSA levels between exposed and unexposed workers. The results of the analysis of the correlation between blood Cd and PSA were found to be statistically significant. The results of our study are similar to those of Zeng et al. ${ }^{(18)}$ in China, who found that subjects with a positive digital rectal examination and PSA blood levels above normal limits, have blood Cd levels above normal. The mechanism of the effect of $\mathrm{Cd}$ on PSA levels is to date still unclear. There is some conjecture about the mechanism of the effect of $\mathrm{Cd}$ on plasma PSA.
Several studies have strongly suggested that the effect of $\mathrm{Cd}$ on the occurrence of prostate cancer is through changes in the expression of apoptosis regulator cells and inhibition of cell apoptosis. Barriers to apoptosis of cells are characterized by decreased expression of the caspase 3 gene, p53 oncogenes, decreased RAD51 and increased gadd45 oncogenes and the growth factors c-jun and igf1rb. ${ }^{(18,19)}$

Prostate cell proliferation caused by exposure to $\mathrm{Cd}$ increases the PSA synthesis in prostate cells. The prostate is the main source of PSA production. An increase in serum PSA indicates prostate pathology. Results of research by Mok et al. ${ }^{(20)}$ in Korean males found a relationship of increased risk of prostate cancer with PSA. The risk of prostate cancer increased by $7 \%$ for each increase of $1 \mathrm{ng} / \mathrm{mL}$ PSA.

The results of our study differ from those of $\mathrm{Wu}$ et al. ${ }^{(21)}$ who found that PSA levels are inversely associated with blood cadmium (BCd) and urinary cadmium (UCd) levels.Multivariate logistic regression analysis showed that men with PSA $\geq 4.0 \mathrm{ng} / \mathrm{mL}$ had an odds ratio ( $\mathrm{OR}=0.4$; $95 \% \mathrm{CI}=0.1-0.9)$ to have $\mathrm{BCd}$ of $>0.49 \mu \mathrm{g} / \mathrm{L}$.

The present study showed a weakly significant association between blood Cd levels and IGF-1. These results support the study of Chen et al. ${ }^{(8)}$ who found increased levels of IGF1 in the liver cells of zebra fish that had been exposed to $\mathrm{Cd}$ and under observation for 12 and 24 hours.

The present study showed a moderately significant association between IGF-1 and PSA. According to research by Saikali et al. ${ }^{(22)}$ IGF-1 significantly increased the invasive capacity of DU145 prostate cancer cells in vitro. The data indicates a regulatory role of IGF-1 signalling via both the phosphatidylinositol-3 kinase (PI3$\mathrm{K})$ and the mitogen activated protein kinase (MAPK) pathways in DU145 prostate carcinoma cells. Phosphorylation of the key elements of these pathways, Akt and the MAPK, following IGF-1 treatment, confirmed the role of the PI3-K and MAPK pathways in IGF-1 signalling and correlated with invasive capacity. 
A meta-analysis by Rowlands et al. ${ }^{(23)}$ confirms that raised circulating $1 \mathrm{GF}-\mathrm{I}$ is positively associated with prostate cancer risk.

These resultswere different from those of Borugian et al. ${ }^{(24)}$ who observed no association of prostate cancer risk with prediagnostic IGFIand a positive association with prediagnostic IGFBP-3 and prostate cancer, but only for the subgroup of black males and only in the third quartile. The interaction between IGF-I and IGFIR is regulated by the IGF-binding proteins (IGFBPs), IGFBP-3 being the most abundant. At tissue level, IGFBP-3 regulates the mitogenic activity and inhibits the anti-apoptotic effect of IGF-I and has been linked to induction of apoptosis. In prostate cancer patients with undetectable PSA levels, their IGFBP-3 levels are expected to be higher, since IGFBP-3 is a substrate of PSA and is proteolytically cleaved by it. The inverse correlation between PSA and IGFBP-3 could make IGFBP-3 a possible biochemical marker of disease control in prostate cancer patients. ${ }^{(25)}$

The present study has limitations such as not performing measurements on IGFBP-3 and not doing more clinical examinations, such as a digital rectalexaminations for confirmation of any abnormality in the prostate of subjects with PSA levels above $4 \mathrm{ng} / \mathrm{L}$.

The clinical implication of this research is that IGF-1 may be used as biomarker of prostate cancer. To achieve these objectives more research is needed that examines the sensitivity and specificity of IGF-1 for the early detection of prostate cancer. Research is also needed to determine other biomarkers of prostate carcinogenesis caused by $\mathrm{Cd}$ exposure by a less expensive and equally valid method for prevention of occupational diseases. Prevention can be done through controls to ensure that welding done in a confined space is provided good ventilation, through measurement of $\mathrm{Cd}$ in the working environment, through education of workers in healthy practices in hygiene, through periodical medical checks and the use of personal protective equipment.

\section{CONCLUSIONS}

The present study showed an association of blood Cd with PSA and IGF-1. PSA and IGF1 can be used for screening of occupational diseases in workers exposed to $\mathrm{Cd}$.

\section{CONFLICT OF INTEREST}

The authors declare that they have no competing interest.

\section{ACKNOWLEDGEMENT}

Acknowledgements are due to the Ministry of Research, Technology, and Higher Education, Republic of Indonesia (Kemenristek dikti) for research grants, to Jenderal Soedirman University and the Institute for Research and Community Service, Faculty of Medicine, for their cooperation and assistance.

\section{CONTRIBUTION}

NR contributed to the design the research, drafting the manuscript and responsible for the final content. NR, S, and LSM contributed to collected, analyzed and interpretate the data. NR contributed to wrote the manuscript, and all authors read and approved the final manuscript.

\section{REFERENCES}

1. Sorahan T. Lung cancer mortality in arsenicexposed workers from a cadmium recovery plant. Occup Med 2009;59:264-6.

2. Lacorte LM, Delella FK, Porto Amorim EM, et al. Early changes induced by short-term lowdose cadmium exposure in rat ventral and dorsolateral prostates. Microsc Res Tech 2011; 75:988-97.

3. Guzel S, Kiziler L, Aydemir B, et al. Association of $\mathrm{Pb}, \mathrm{Cd}$, and $\mathrm{Se}$ concentrations and oxidative damage-related markers in different grades of prostate carcinoma. Biol Trace Elem Res 2012; 145:23-32.

4. Mazaris E, Tsiotras A. Molecular pathways in prostate cancer. Nephro Urol Mon 2013;5:792800. 
5. Shanmugalingam T, Bosco C, Ridley AJ, et al. Is there a role for IGF 1 in the development of second primary cancers? Cancer Med 2016;5: 3353-67.

6. De Coster S, Koppen G, Bracke M, et al. Pollutant effects on genotoxic parameters and tumor-associated protein levels in adults: a cross sectional study. Environ Health 2008;7:26. doi: 10.1186/1476-069X-7-26.

7. Pizent A, Èolak B, Kljakoviæ GZ, et al. Prostatespesific antigen in serum in relation to blood lead concentration and alcohol consumption in men. Arh Hig Rada Toksiko 2008;60:69-78.

8. Chen, Ying Y, Zhu JY, et al. Effects of cadmium on cell proliferation, apoptosis, and protooncogene expression in Zebrafish liver cells. Aquatic Toxicol 2014;157:196-206.

9. Chen C, Xun PC, Nishijo M, et al. Cadmium exposure and risk of prostate cancer: a metaanalysis of cohort and case-control studies among the general and occupational populations. Sci Rep 2016;6:25814. DOI: 10.1038/srep25814.

10. Ali H, Khan E, Sajad MA. Phytoremediation of heavy metals - concepts and applications. Chemosphere 2013;91:869-81.

11. Moitra S, Brashier BB, Sahu S. Occupational cadmium exposure-associated oxidative stress and erythrocyte fragility among jewelry workers in India. Am J Ind Med 2014;57:1064-72.

12. Adams SV, Passarelli MN, Newcomb PA. Cadmium exposure and cancer mortality in the Third National Health and Nutrition Examination Survey cohort. Occup Environ Med 2012;69:153-6.

13. Benoff S, Hauser R, Marmar JL, et al. Cadmium concentrations in blood and seminal plasma: correlations with sperm number and motility in three male populations (infertility patients, artificial insemination donors, and unselected volunteers). Mol Med 2009;15:248-62.

14. Golbabaei F, Seyedsomea M, Ghahri A, et al. Assessment of welders exposure to carcinogen metals from manual metal arc welding in gas transmission pipelines, Iran. Iran J Public Health 2012;41:61-70.

15. Idham M. Studi tentang pemaparan fume kadmium dan penggunaan alat pelindung diri dengan kadar kadmium dalam darah pekerja di Bagian Pengelasan PT. YIMM tahun 2004. [Thesis]. Depok: Program Sudi Magister Kesehatan dan Keselamatan Kerja Fakultas Kesehatan Masyarakat Universitas Indonesia; 2004.
16. He P, Lu Y, Liang Y, et al. Exposure assessment of dietary cadmium: findings from Shanghainese over 40 years, China. BMC Public Health 2013; 13:590. doi: 10.1186/1471-2458-13-590.

17. Mohmand J, Eqani SA, Fasola M, et al. Human exposure to toxic metals via contaminated dust: Bio-accumulation trends and their potential risk estimation. Chemosphere 2015;132:142-51.

18. Zeng X, Jin T, Jiang X, et al. Effects on the prostate of environmental cadmium exposure across-sectional study population study in China. Biometals 2004;17:559-65.

19. El-Atta HM, El-Bakary AA, Attia AM, et al. DNA fragmentation, caspase 3 and prostatespecific antigen genes expression induced by arsenic, cadmium, and chromium on nontumorigenic human prostate cells. Biol Trace Elem Res 2014;162:95-105.

20. Mok Y, Kimm H, Shin SY, et al. Screening prostate-specific antigenconcentration and prostatecancer mortality: the Korean Heart Study. Urology 2015;85:1111-6.

21. Wu CC, Pu YS, Wu HC, et al. Reversed association between levels of prostate specific antigen and levels of blood cadmium and urinary cadmium. Chemosphere 2011;83:1188-91.

22. Saikali Z, Setya H, Singh G, et al. Role of IGF$1 /$ IGF-1R in regulation of invasion in DU145 prostate cancer cells. Cancer Cell Int 2008;8:10. doi: 10.1186/1475-2867-8-10.

23. Rowlands MA, Gunnell D, Harris R, et al. Circulating insulin-like growth factor peptides and prostate cancer risk: a systematic review and meta-analysis. Int J Cancer 2009;124:2416-29.

24. Borugian MJ, Spinelli JJ, Sun Z, et al. Prostate cancer risk in relation to insulin-like growth factor (IGF)-I and IGF-binding protein-3: aprospective multiethnic study. Cancer Epidemiol Biomarkers Prev 2008;1:252-4.

25. Corrêa LL, Neto LV, Lima GAB, et al. Insulinlike growth factor ( $\mathrm{IgF}$ )-I, IgF binding protein3 , and prostate cancer: correlation with gleason score. Int. Braz J Urol 2015;41:110-5. doi: 10.1590/S1677-5538.IBJU.2015.01.15. 